\title{
Small mammal communities of the Mongolian Gobi Region: diversity and impacts of mining
}

\author{
Setev Shar, Igor V. Moroldoev* \& Davaa Lkhagvasuren
}

\begin{abstract}
In the Gobi region of Mongolia, mining activities have developed rapidly over the last 20 years. The development of the mining sector is important for the economic growth of Mongolia, but local communities have always been critical of its negative impact. The purpose of our study was to determine the mining effects on the small mammal community in the Gobi region. In order to achieve this goal, we estimated the species diversity and abundance of small mammal populations in the vicinity of the Tavan Tolgoi and Oyu Tolgoi mines in Umnugobi aimag of Mongolia in August 2017 and in August 2018. Generally, mining activities in the Gobi region have negative impacts on small mammal communities, and at the same time effects differ on the different species of small mammals.
\end{abstract}

How to cite this article: Shar S., Moroldoev I.V., Lkhagvasuren D. 2020. Small mammal communities of the Mongolian Gobi Region: diversity and impacts of mining // Russian J. Theriol. Vol.19. No.1. P.94-98. doi: 10.15298/rusjtheriol.19.1.10.

KEY WORDS: diversity, small mammals, communities, impact of mining, Mongolian Gobi.

Setev Shar [shar@num.edu.mn],Department of Biology, School of Arts and Sciences, National University of Mongolia, Ikh Surguuliin gudamj-1, p.o.box-46a/402, Ulaanbaatar 14201, Mongolia; IgorV.Moroldoev [igmor@list.ru], Institute of Systematics and Ecology of Animals, Siberian Branch of the Russian Academy of Sciences, Frunze str. 11, Novosibirsk 630091, Russia; Davaa Lkhagvasuren [lkhagvasuren@num.edu.mn], Department of Biology, School of Arts and Sciences, National University of Mongolia, Ikh Surguuliin gudamj-1, p.o.box-46a/523, Ulaanbaatar 14201, Mongolia.

\section{Сообщества мелких млекопитающих Монгольской Гоби: разнообразие и влияние горнодобывающей промышленности}

\author{
С. Шар, И.В. Моролдоев*, Д. Лхагвасурен
}

\begin{abstract}
РЕЗЮМЕ. В течение последних 20 лет в пустыне Гоби (Монголия) бурно развивается добыча полезных ископаемых. Местное население критически относится к негативному воздействию горнодобывающей промышленности, хотя эта отрасль важна для экономического роста страны. Целью нашего исследования было определение влияния добычи полезных ископаемых на население мелких млекопитающих в регионе Гоби. Для этого мы оценили видовое разнообразие и численность популяций мелких млекопитающих в окрестностях шахт Таван-Толгой и Оюу-Толгой в Южно-Гобийском (Умнуговь) аймаке Монголии в августе 2017 г. и в августе 2018 г. В целом, добыча полезных ископаемых имеет негативное воздействие на сообщества млекопитающих, однако уровень этого воздействия различается у различных видов мелких млекопитающих.
\end{abstract}

КЛЮЧЕВЫЕ СЛОВА: разнообразие, мелкие млекопитающие, сообщества, влияние горнодобывающей промышленности, Монгольская Гоби.

\section{Introduction}

The Gobi region of Mongolia is located on the northern edge of the steppe region and north of the Central Asian Desert, and it is a diverse habitat for small mammals. During the last 20 years, coal and gold-copper mines have been established in Tsogttsetsii and Khanbogd soums of Umnugovi aimag, where they are operating

\footnotetext{
* Corresponding author
}

continuously. Foreign researchers have reported that creating licensing buffer zones in Mongolia's Gobi region and some protected areas causes environmental problems (Farrington, 2005). At present, around 96.500 hectares of land are in the Tsogttsetsii soum, which is affected by coal mining in Tavan Tolgoi, and approximately 14.785 hectares in the Khanbogd soums are affected by Oyu Tolgoi's copper-gold production.

There are some 50 species of small mammals in the Gobi region of Mongolia (Bannikov, 1954; Dulamtseren, 
1970; Sokolov \& Orlov, 1980). Further studies of Russian scientists (Rogovin \& Shenbrot, 1995) added over 15 rodent species to the mammal list of the Gobi region.

We have chosen this topic because there are still no data on the impact of the mines in the Gobi region. The purpose of our study was to determine whether a mine affects a small mammal community in the Gobi region. In order to achieve this objective, a study of small mammal species found near the Tavan Tolgoi coal mine in the South Gobi province and the Oyu Tolgoi copper and gold mines was carried out in August 2017 and in August 2018, taking into account diversity and population density. Afterwards, computations of the small mammals in the mining habitat were compared with the results received in the control area. Based on these findings, attempts were made to determine whether the mines have a negative impact on the small mammal community. The results of field surveys are outlined in this article.

\section{Materials and methods}

In 2017 and 2018, we captured a small mammals in the Tavan Tolgoi coal mine and Oyu Tolgoi copper and gold mines. At the same time, we selected a second area of survey control, which is located far from the mines. Based on quantitative data such as diversity and abundance of the small mammal species we conducted field surveys to determine whether mines impacted small mammals.

During this study, we conducted 2673 trap/nights, totalling 14 species and 419 individuals: Mongolian gerbil (Meriones unguiculatus), midday gerbil (M. meridianus), Mongolian hamster (Allocricetulus curtatus), grey dwarf hamster (Cricetulus migratorius), Campbell's hamster (Phodopus campbelli), Roborovski's hamster (P. roborovskii), long-eared hedgehog (Hemiechinus auritus), Gobi jerboa (Allactaga bullata), Siberian jerboa (A. sibirica), Balikun jerboa (A. balikunica), hairy-footed jerboa (Dipus sagitta), five-toed pygmy jerboa (Cardiocranius paradoxus), thick-tailed pygmy jerboa (Salpingotus crassicauda), and house mouse (Mus musculus).

We used live traps (Sherman type) in the field study of small mammals. The live traps were positioned $6 \mathrm{~m}$ apart and placed linearly at $100-500 \mathrm{~m}$ from the mine site. Each trap contained a single bait type (chunks of banana or peanut butter, sunflower seeds, or sardines). We used the light-emitting method for mammals active in the night, and we captured 101 individuals from five jerboa species of the family Dipodidae.

We selected a field site for small mammalian community research at 100-500 $\mathrm{m}$ away from the Tavan Tolgoi coal mine site (Fig. 1) in Tsogttsetsii soum (N4342'59", E105²8'40", elevation $1502 \mathrm{~m}$ a.s.1.). We also selected a site of small mammals at 100-500 m from the Oyu Tolgoi copper-gold mining area in Khanbogd soum of South Gobi province (N43 $01^{\circ} 57^{\prime \prime}$, E106 ${ }^{\circ} 7^{\prime} 15^{\prime \prime}$, elevation $1203 \mathrm{~m}$ a.s.1.). These sites

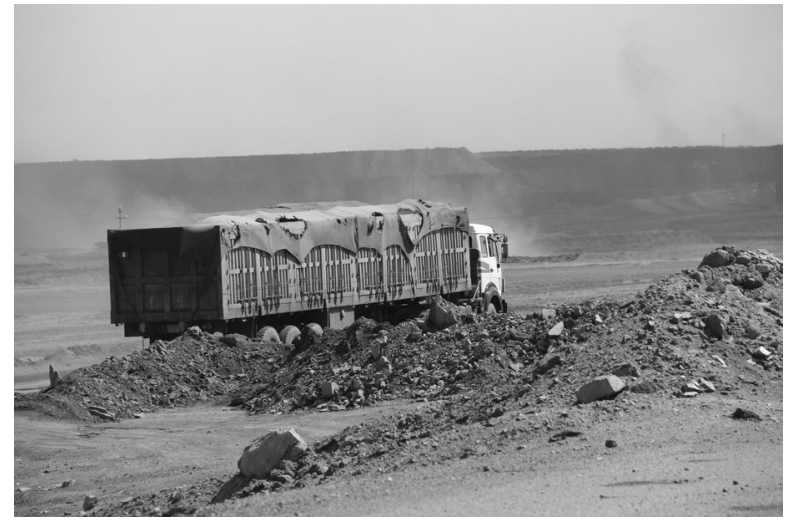

Fig 1. View of Tavan Tolgoi mine.

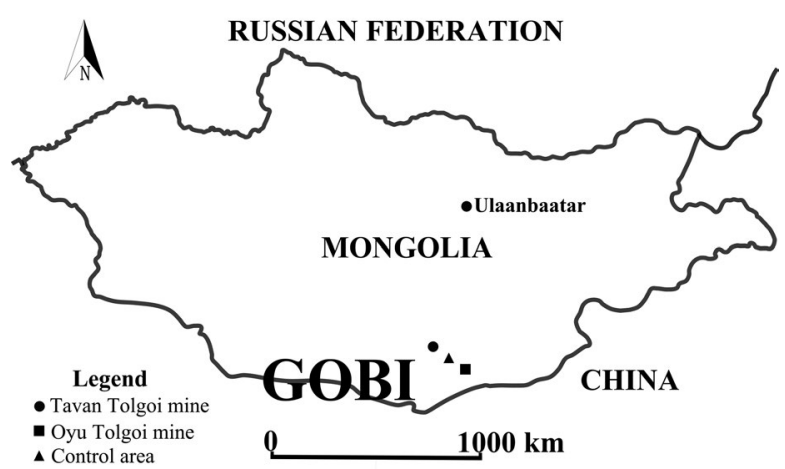

Fig 2. Field sites in Mongolian Gobi region.

were selected as close to the mine as possible. In order to compare the abundances of small mammals found in these areas, one field control area (N43'17'32", E106 12 '49", elevation $1395 \mathrm{~m}$ a.s.1.) was selected to compare the abundances of mammals found in the mines (Fig. 2). We obtained a number of small mammals per 100 trap/nights with the formula $N=100$ n/at (where $n$ is the total number of captured small mammals; $a$ is the number of traps; $t$ is the time of capture); standard error is calculated by $S N=100 \sqrt{ }$ n/at.

We used parameters of species abundance, the Shannon diversity index, the Pielou evenness index, and the Simpson dominance index to analyse the small mammals' community structure. The Shannon diversity index was measured as $H=-\sum p_{i *} \ln p_{i}$, where $p_{i}$ is the proportion of individuals belonging to the $i$-th species $\left(n_{i} / N\right)$. The Pielou evenness index is $J=H_{i} / H_{\max }=H_{i} / \ln S$, where $S$ is the total number of species in the community. The Simpson dominance index was calculated as $C=$ $\Sigma(n / N)^{2}=\Sigma\left(p^{i}\right)^{2}$.

\section{Results}

A total of 419 individuals from five species of small mammals were found around the Tavan Tolgoi and Oyu Tolgoi mines using Sherman traps. Around the Tavan 
Tolgoi mine, the most abundant species is the Mongolian gerbil, with $12.6 \pm 0.1$ individuals per 100 trap/nights. The surroundings of the Oyu Tolgoi mine are marked with low species diversity and population density, and the Mongolian gerbil is the more dominant species. We captured 244 individuals in the control area, a habitat without a mine, where the Roborovski's hamster occupies $58.2 \%$ of the total abundance of small mammals.

The species diversity and relative abundance of small mammals in the three studies sites are shown in Table 1, and the results of counting the density of Dipodidae species by car are presented in Table 2 .

Communities of small mammals of the Tavan Tolgoi and Oyu Tolgoi mines consist of five and three species, respectively, and the highest species diversity was observed in the communities of the control area (habitat without a mine, Table 3). The Tavan Tolgoi mine is characterised by the lowest level of the Shannon diversity index, and the most diverse is the control area.
The Pielou evenness index, which showed how even the community was numerically, was high in Oyu Tolgoi. It can be explained by the low species and individual abundance of small mammals near Oyu Tolgoi. At the same time, the Pielou evenness index was high enough in the control area, as the community there is characterised by even numerical distribution of different species. The Simpson dominance index increased with a significant dominance of one or more species. In the community of Tavan Tolgoi, there were only five species, and over $92 \%$ of the individuals belonged to one species, Meriones unguiculatus. For this reason, the dominance index in this community increased dramatically. The lowest value of the dominance index, which indicates a large number of species, but low numbers, was found in the community of the control area. In small mammal communities of Oyu Tolgoi, Simpson's index was 0.51 because of the low species diversity and high numerical advantage of the Mongolian gerbil.

Table 1. The species diversity and relative abundance of small mammal populations around the Tavan Tolgoi and Oyu Tolgoi mines.

\begin{tabular}{|l|c|c|c|c|c|c|}
\hline \multirow{2}{*}{ Species } & \multicolumn{2}{|c|}{$\begin{array}{c}\text { Around Tavan Tolgoi mine } \\
\text { (for 1215 trap/nights) }\end{array}$} & \multicolumn{2}{c|}{$\begin{array}{c}\text { Around Oyu Tolgoi mine } \\
\text { (for 729 trap/nights) }\end{array}$} & \multicolumn{2}{c|}{ Control area (for 729 trap/nights) } \\
\cline { 2 - 7 } & $\begin{array}{c}\text { number of } \\
\text { individuals }\end{array}$ & $\begin{array}{c}\text { per 100 trap/ } \\
\text { night }\end{array}$ & $\begin{array}{c}\text { number of } \\
\text { individuals }\end{array}$ & $\begin{array}{c}\text { per 100 } \\
\text { trap/night }\end{array}$ & $\begin{array}{c}\text { number of } \\
\text { individuals }\end{array}$ & per 100 trap/night \\
\hline Meriones unguiculatus & 154 & $12.6 \pm 0.1$ & 6 & $0.8 \pm 0.3$ & 9 & $1.2 \pm 0.4$ \\
\hline M. meridianus & 2 & $0.2 \pm 0.1$ & 1 & $0.1 \pm 0.1$ & 54 & $7.4 \pm 1.0$ \\
\hline Allocricetulus curtatus & - & - & - & - & 8 & $1.1 \pm 0.4$ \\
\hline Cricetulus migratorius & 1 & $0.08 \pm 0.08$ & - & - & 6 & $0.8 \pm 0.2$ \\
\hline Phodopus campbelli & - & - & - & - & 20 & $2.7 \pm 0.6$ \\
\hline P. roborovskii & - & - & - & - & 142 & $19.5 \pm 1.6$ \\
\hline Hemiechinus auritus & 6 & $0.5 \pm 0.2$ & - & - & 3 & $0.4 \pm 0.2$ \\
\hline Cardiocranius paradoxus & - & - & - & - & 2 & $0.3 \pm 0.1$ \\
\hline Mus musculus & 3 & $0.2 \pm 0.1$ & 2 & $0.2 \pm 0.1$ & - & - \\
\hline Total number & 166 & $13.6 \pm 1.05$ & 9 & $1.2 \pm 0.4$ & 244 & $33.4 \pm 2.1$ \\
\hline
\end{tabular}

Table 2. The result of counting the density of Dipodidae species by car.

\begin{tabular}{|l|c|c|c|c|c|c|}
\hline \multirow{2}{*}{\multicolumn{2}{|c}{ Species }} & \multicolumn{2}{|c|}{ Around Tavan Tolgoi mine } & Around Oyu Tolgoi mine & \multicolumn{2}{c|}{ Control area } \\
\cline { 2 - 7 } & $\begin{array}{c}\text { number of } \\
\text { individuals }\end{array}$ & Per 1 ha & $\begin{array}{c}\text { number of } \\
\text { individuals }\end{array}$ & Per 1 ha & $\begin{array}{c}\text { number of } \\
\text { individuals }\end{array}$ & Per 1 ha \\
\hline Allactaga bullata & 9 & 2.1 & 9 & 1.8 & 12 & 1.1 \\
\hline Allactaga sibirica & - & - & 5 & 1.04 & 3 & 0.3 \\
\hline Dipus sagitta & 2 & 0.5 & - & - & 37 & 3.4 \\
\hline Allactaga balikunica & - & - & 4 & 0.8 & - & - \\
\hline Cardiocranius paradoxus & 4 & 0.9 & 3 & 0.6 & 13 & 1.2 \\
\hline Total number & 15 & 3.5 & 21 & 4.3 & 65 & 6.0 \\
\hline
\end{tabular}


Table 3. Diversity indices of small mammal communities around mines.

\begin{tabular}{|l|c|c|c|c|c|}
\hline \multicolumn{1}{|c|}{ Locality } & S & N & H & J & C \\
\hline Tavan Tolgoi mine & 5 & 166 & 0.35 & 0.22 & 0.86 \\
\hline Oyu Tolgoi mine & 3 & 9 & 0.85 & 0.77 & 0.51 \\
\hline Control area & 8 & 244 & 1.27 & 0.61 & 0.40 \\
\hline
\end{tabular}

Footnotes: $\mathrm{S}$ - species abundance, $\mathrm{N}$ - number of individuals, $\mathrm{H}$ - Shannon diversity index, $\mathrm{J}-$ Pielou evenness index, $\mathrm{C}-$ Simpson dominance index

\section{Discussion}

There are many research reports devoted to impact of mining activities on small mammals. For example, depending on factors such as vegetation type and soil humidity, there is a general trend that small mammal communities are diverse. Depending on the diversity of habitats in the area, the abundance of small mammals varies (Emmons, 1984; Tews et al., 2004).

The abundance of generalist species is high in all areas. One reason for this is that there is a high level of competition between species, where abundance of mammal populations is high (Bergallo, 1994). For example, in a Brazilian Amazon forest investigation, the abundance of mammals was high even in sites located close to the some of the large iron deposits (Malcolm, 1997; Ochoa, 2000; Lambert et al., 2006; Ardente et al., 2016).

It is interesting to note that the abundance of Gobi jerboa, hairy-footed jerboa, and Mongolian gerbil species at 100-500 $\mathrm{m}$ from the Tavan Tolgoi mine site was higher than that of other species, even higher than in the desert without mining. The reason is that welladapted generalist species in the Gobi environment are widespread around the mine and, on the other hand, decrease the impact of mammals on daily and night raptors and carnivorous mammals in the vicinity of the mine. This may be due to the decreased number of carnivores due to mining activities. As a result of research on the abundance of rodents in the vicinity of the mines, the number of rodents was higher in the vicinity of the mines (Fonseca \& Robinson, 1990; Caughley, 1994; Chiarello, 2008).

According to the above data, the abundance of small mammals is high in the vicinity of the mines, but in the less disturbed areas of the mine. The main reason for this is dependent on factors such as generalist rodents and predatory birds and carnivores.

\section{Conclusions}

The small mammal population abundance per 100 trap/nights is $13.6 \pm 1.05$ around the Tavan Tolgoi mine and $1.2 \pm 0.4$ around the Oyu Tolgoi mine. However, the small mammal population abundance per 100 trap/ nights was $33.4 \pm 2.1$ in the desert area without a mine.
The Mongolian gerbil dominated around the Tavan Tolgoi mine within the period covered by the study, but Roborovski's hamster dominated in areas without a mine. According to these findings, the Mongolian gerbil has not been sensitive to mining impacts due to adaptation to human settlements, whereas the Roborovski's hamster is highly sensitive to mining impacts. Therefore, our findings indicate that small mammal species have very different sensitivities to the mine's impact.

According to our findings, the abundance of small mammals has been characterised by the density of roads, high mobility, and noise in the area around the mines, but the abundance of populations of small mammals has been high in the silent desert. According to this, mining activities in the Gobi region have negative impacts on small mammal communities. However, the results of this study show that effects differ on the various species of small mammals.

The small mammals resistant species are more abundant, and environmentally sensitive species are less abundant in the vicinities of the Tavan Tolgoi coal mine, and Oyu Tolgoi gold-copper mine in the Gobi region of Mongolia.

ACKNOWLEDGMENTS. We would like to thank all those who have supported this research and the Asian Research Fund at the National University of Mongolia. This work has been done within the framework of the project "Impacts of mine activities on small mammals communities in the Gobi region of Mongolia" supported by the Asia Research Center, Mongolian and Korean Foundation for Advanced Studies, Korea.

\section{References}

Ardente N.C., Ferreguetti A.C., Gettinger D., Leal P., MendesOliveira A.C., Martins-Hatano F. \& Bergallo H.G. 2016. Diversity and impacts of mining on the non-volant small mammal communities of two vegetation types in the Brazilian Amazon // PLoS ONE. Vol.11. No.11. e0167266.

Bannikov A.G. 1954. [Mammals of the Mongolian People's Republic]. Moscow: AN SSSR. 669 p. [in Russian].

Bergallo H.G. 1994. Ecology of a small mammal community in an Atlantic Forest area in southeastern Brazil // Studies on Neotropical Fauna and Environment. Vol.29. No.4. P.197-217. 
Caughley G. 1994. Directions in conservation biology // Journal of Animal Ecology. Vol.63. No.2. P.215-244.

Chiarello A.G. 2008. Density and population size of mammals in remnants of Brazilian Atlantic Forest // Conservation Biology. Vol.14. No.6. P.1649-1657.

Dulamtseren S. 1970. [Guidebook to the mammals of the Mongolian People's Republic]. Ulaanbaatar: Publishing House of the Mongolian Academy of Sciences. 105 p. [in Mongolian].

Emmons L. 1984. Geographic variation in densities and diversities of non-flying mammals in Amazonia // Biotropica. Vol.16. No.3. P.210-222.

Farrington J. 2005. The impact of mining activities on Mongolia's protected areas: a status report with policy recommendations // Integrated Environmental Assessment and Management. Vol.1. No.3. P.283-289.

Fonseca G. \& Robinson J. 1990. Forest size and structure: competitive and predatory effects on small mammal communities // Biological Conservation. Vol.53. No.4. P.265-294.

Lambert T.D., Malcolm J.R. \& Zimmerman B.L. 2006. Amazonian small mammal abundances in relation to habitat structure and resource abundance // Journal of Mammalogy. Vol.87. No.4. P.766-776.

Malcolm J.R. 1997. Biomass and diversity of small mammals in Amazonian forest fragments // Whitmore T.C., Laurance W.F. \& Bierregaard R.O. (eds.). Tropical forest remnants: ecology, management and conservation of fragmented communities. Chicago: University of Chicago Press. P.207-221.

Ochoa G. 2000. The effects of logging on the diversity of small mammals in the lowland forests of the Venezuelan Guayana Region // Biotropica. Vol.32. No.1. P.146-164.

Rogovin K. \& Shenbrot G. 1995. Geographical ecology of Mongolian desert rodent communities // Journal of Biogeography. Vol.22. No.1. P.111-128.

Sokolov V.E. \& Orlov V.N. 1980. [Guide to the mammals of the Mongolian People's Republic]. Moscow: Nauka. 351 p. [in Russian].

Tews J., Brose U., Grimm V., Tielbörger K., Wichmann M.C., Schwager M. \& Jeltsch F. 2004. Animal species diversity driven by habitat heterogeneity/diversity: the importance of keystone structures // Journal of Biogeography. Vol.31. No.1. P.79-92. 